\title{
SPHK2 Gene
}

National Cancer Institute

\section{Source}

National Cancer Institute. SPHK2 Gene. NCI Thesaurus. Code C128470.

This gene is involved in the biosynthesis of sphingosine 1- phosphate. 